\title{
Article \\ Trading Activities and the Volatility of Return on Malaysian Crude Palm Oil Futures
}

\author{
Xiu Wei Yeap and Hooi Hooi Lean *D
}

Citation: Yeap, Xiu Wei, and Hooi Hooi Lean. 2022. Trading Activities and the Volatility of Return on Malaysian Crude Palm Oil Futures. Journal of Risk and Financial Management 15: 34. https:// doi.org/10.3390/jrfm15010034

Academic Editor: Aviral Kumar Tiwari

Received: 29 September 2021 Accepted: 30 November 2021 Published: 13 January 2022

Publisher's Note: MDPI stays neutral with regard to jurisdictional claims in published maps and institutional affiliations.

Copyright: (C) 2022 by the authors. Licensee MDPI, Basel, Switzerland. This article is an open access article distributed under the terms and conditions of the Creative Commons Attribution (CC BY) license (https:// creativecommons.org/licenses/by/ $4.0 /)$.
Economics Program, School of Social Sciences, Universiti Sains Malaysia, Gelugor 11800, Penang, Malaysia; yeapxiuwei@gmail.com

* Correspondence: learnmy@gmail.com

\begin{abstract}
Trading activities represent the flow of market information to the investors. This paper examines the effect of trading activities, i.e., trading volume and open interest, on the volatility of return for Malaysian Crude Palm Oil Futures. The GARCH model is applied by adding the expected and unexpected elements of trading activities (trading volume and open interest) as the independent variables. The results show that there is a negative contemporaneous relationship between the expected volume and volatility, but that a positive relationship exists between unexpected volume and volatility. On the contrary, the expected and unexpected open interest mitigate the volatility. Therefore, both trading volume and open interest should be considered together when information flows into the market.
\end{abstract}

Keywords: crude palm oil futures; trading volume; open interest; market information

JEL Classification: G14; Q10

\section{Introduction}

The mixture of distribution hypothesis (MDH) suggested by Clark (1973) and the sequential information arrival hypothesis (SIAH) suggested by Copeland (1976) have been widely used to document the relationship between price changes and trading volume. According to Ezzat and Kirkulak-Uludag (2016), MDH assumes that all market participants receive new information simultaneously and reach a new price equilibrium immediately without partial equilibrium. Therefore, return volatility and trading activities are correlated contemporaneously. On the other hand, SIAH assumes that new information is disseminated to market participants one at a time, such that a sequence of partial equilibrium is achieved prior to a new price equilibrium (Karpoff 1987). This means that the return volatility and trading activities are not correlated contemporaneously because there is a lead-lag relationship between return volatility and trading activities. Both price and volume changes are due to the uncertainty of information flows into the market.

First and foremost, MDH shows that there is a positive contemporaneous relationship between price changes and trading volume (Epps and Epps 1976; Rogalski 1978; Tauchen and Pitts 1983; Harris 1986; Lamoureux and Lastrapes 1990). Trading volume is chosen as a mixed variable to capture price volatility. Black (1986), Kim and Verrecchia (1991), and Daigler and Wiley (1999) explained that the general public, who do not have clear information, are affected by the noise effect. The trading activity (trading volume and open interest) provides information regarding the aggregate expectation of investors to the futures exchanges (Boonvorachote and Lakmas 2016). Karpoff (1987) surveyed the past studies and found that trading volume is associated with price increases in the equity market. The momentum of the price increases is greater than the price decreases due to the restriction on information in the short sale activity. Due to the limitation of MDH, the SIAH also portrays a positive relationship between price changes and trading volume (Copeland 1976; Jenning et al. 1981). 
According to Go and Lau (2020a), the prices of the commodity markets normally move in different ways, which is difficult to explain rationally when a large number of financial investors influx the market. Therefore, it will be interesting to find out to what extent trading volume and open interest influence the market. Go and Lau (2020a) stated that crude palm oil is one of the most highly consumed vegetable commodities in the world and that it makes a large contribution to Malaysia's economy. Malaysia is one of the major producers of crude palm oil, and, hence, its crude palm oil futures exchange market is actively traded. Crude palm oil futures are traded on Bursa Malaysia Derivatives (BMD) Berhad and the availability of contract is up to 24 months. However, the most active and liquid contract is the three-month contract (Go and Lau 2020a).

It is important to investigate the relationship between the volatility of return and trading volume on the Malaysian Crude Palm Oil Futures for various reasons. First, the analysis of the intertemporal relationship between the volatility of return and trading volume may provide additional insights to model the volatility of return of the crude palm oil futures price in Malaysia. Second, an increase in trading volume may lead to high variability in the futures markets (Mougoué and Aggarwal 2011). Hence, this paper can provide market participants with a tool to detect market manipulations. Third, Malaysia is the second largest producer of crude palm oil in the world after Indonesia. Crude palm oil is the fourth largest contributor to the gross national income (GNI) of Malaysia, providing eight percent of GNI in 2011 (Dompok 2011). It is important to analyse crude palm oil futures because the development of the crude palm oil futures market is important to Malaysia's economy (Liew and Brooks 1998).

Many empirical studies, such as Epps and Epps (1976), Rogalski (1978), Tauchen and Pitts (1983), Harris (1986), and Lamoureux and Lastrapes (1990), showed a positive relationship between the volatility of return and the trading volume in futures exchanges. However, Liew and Brooks (1998) found that the relationship between the volatility of return and trading volume is negative for the crude palm oil futures market. The negative relationship of volatility-volume is not supported by MDH or SIAH. On the other hand, some other literature, such as Bessembinder and Seguin (1993), Ragunathan and Peker (1997), Watanabe (2001), and Boonvorachote and Lakmas (2016), used open interest as a proxy for the trading activity when examining the volatility of return in the futures exchanges. In their studies, Chan et al. (2004), and Ripple and Moosa (2009) found that the volatility of return increases when open interest becomes small, which is also not supported by either the MDH or the SIAH. However, Liew and Brooks (1998), and Girma and Mougoue (2002) found that the relationship between the volatility of return and open interest is positive and supported by both the MDH and SIAH. Nevertheless, Liew and Brooks (1998), Fung and Patterson (1999), Girma and Mougoué (2002), Chan et al. (2004), and Ripple and Moosa (2009) employed both trading volume and open interest to examine the volatility of return in currency and futures markets. Hence, it will be more interesting to apply both trading volume and open interest as proxy information to examine the volatility of return on Malaysian Crude Palm Oil Futures.

This paper extends the MDH and SIAH frameworks by adding both trading volume and open interest to examine the volatility of return on the Malaysian Crude Palm Oil Futures. Moreover, the trading volume and open interest are partitioned into expected and unexpected components using forecasting approaches. By partitioning this information into expected and unexpected components, we can investigate whether the proxy information has a homogeneous effect on the volatility of return and allow each component to have a separable effect on the volatility of return. The unexpected components may be affected by unpredictable noise, such as financial crises and trade wars in agricultural products, which may lead to a sudden increase or decrease in trading activity. On the other hand, the expected components are reflected by common fluctuations in the trading activity, which may cause volatility clustering (Bessembinder and Seguin 1993).

This paper makes several contributions. For the first time, we include both trading volume and open interest with partitioning into expected and unexpected components to 
examine the volatility of return of crude palm oil futures. The unexpected trading volume and open interest can be observed as the new information flow (unexpected shock) to the crude palm oil futures market. Second, this paper investigates both contemporaneous and lead-lag relationships of trading volume and open interest on the volatility of return, which was missing in the literature. Third, this research will provide useful information to investors to better understand the trading activities of Malaysian Crude Palm Oil Futures in their investment strategies and risk management.

The organization of this paper is described as follows: the next section is the literature review. Sections 3 and 4 provide the data description and research methodology. Section 5 reports and discusses the empirical results. The last section concludes the study.

\section{Literature Review}

Two theoretical models, i.e., $\mathrm{MDH}$ and SIAH, are used to explain the correlation between the price changes and trading volume. Both models present the relationship between trading volume and price volatility, which are driven by information flows in the market.

Clark (1973) presented the Central Limit Theorem, which is the limit distribution that is applied to the distribution of price changes. When the new information flows to the exchange, the 'info' speculators would increase the trading volume, and there is a large price change. This large price change is due to the trading volume, which affects the price in a single direction, providing the short sale is prohibited. When the information is widely spread into the market, all the speculators reconsider their expectations on trading activity and the price variability, which leads to a lower trading volume.

Epps and Epps (1976), and Rogalski (1978) measured the intercorrelation of pricevolume on the stock markets. They found that the stock price and trading volume have a positive relationship, which is consistent with MDH. Pyun et al. (2000), Canarella and Pollard (2003), and Ezzat and Kirkulak-Uludag (2016) also found a positive correlation between price changes and changes in trading volume in the Korean, Russian, and Arab Saudi stock markets, respectively. Slim and Dahmene (2016) found a positive relation between trading volume and the volatility of return in CAC40 stocks, while Koubaa and Slim (2019) found the same result in five developed stock markets and four emerging stock markets. However, Kao et al. (2019) found an asymmetric contemporaneous relationship between trading volume and the volatility of return in the S\&P 500 VIX Futures Index.

Besides stock markets, the literature on the currency exchanges is also quite rich. Grammatikos and Saunders (1986) presented a positive contemporaneous relationship between trading volume and price volatility in five currency exchanges, i.e., German mark, the Swiss franc, the British pound, the Canadian dollar, and the Japanese yen. Biswal and Jain (2019) used the spot exchange rate and the futures exchange rate of India, while Sensoy and Serdengeçti (2019) applied spot and forward in Turkey; however, both found a positive relationship between trading volume and volatility of return. Interestingly, Mougoué and Aggarwal (2011) found a negative relationship between the trading volume and volatility of return for the British pound, Japanese yen, and Canadian dollar against the US dollar, which is not consistent with the MDH. Kumar (2019) also found a negative contemporaneous relationship between trading volume and volatility of return for the exchange rate of the US dollar, Euro, British pound, and Japanese yen against the Indian rupee.

With the increased interest in cryptocurrency in recent years, we found two related studies on cryptocurrency. Balcilar et al. (2017) found that there is an insignificant relationship between trading volume and volatility of return in the Bitcoin index. However, Bouri et al. (2019) found that there is a relationship between trading volume and the returns in extreme negative and positive cases on seven leading cryptocurrencies.

There are limitations in MDH. The MDH is built via a single static latent mixing variable, which cannot capture the short-run dynamic of volatility of return (Darolles et al. 2017). The lead-lag relationship can be captured with an alternative hypothesis. SIAH 
states that when the information is received sequentially, both trading volume and changes in price are due to the movement of the demand curve of the speculators. Copeland (1976, 1977), and Copeland and Friedman (1987) assumed that only sequential information flows to the speculators during open trading. The speculators will change their demand curve, which is observed by the trading volume due to different expectations on the information received. Graczyk and Queiros (2018) found that the relationship of trading volume and volatility of return for the Dow Jones Industrial Average is supported by both MDH and SIAH. Kao et al. (2019) found that both the contemporaneous and lead-lag positive relationships exit in the higher regimes for trading volume and volatility of return.

The GARCH approaches are commonly used to examine the SIAH and MDH on the relationship between price variability and volume changes. Lamoureux and Lastrapes (1990) applied GARCH models to examine the relationship between the trading volume and volatility of 20 actively traded stocks on the Chicago Board Options Exchange (CEOB). Chen et al. (2001), Lee and Rui (2002), and Chuang et al. (2012) used GARCH models to test the relations of the stock return, trading volume, and volatility of return for various stock markets.

Although Liew and Brooks (1998) employed both trading volume and open interest to examine the volatility of return on the crude palm oil futures exchange in Malaysia, they did not investigate the lead-lag relationship. Additionally, while Go and Lau (2016), and Go and Lau (2020a) investigated the trading volume and volatility of the return relationship on the Malaysian Crude Palm Oil Futures, they did not consider open interest as a proxy.

Bessembinder and Seguin (1993), Ragunathan and Peker (1997), Watanabe (2001), and Pati (2008) recommended that open interest and trading volume can be partitioned into expected and unexpected components to examine the risk of return in the futures markets. The unexpected components cannot be foreseen or predicted due to the noisy information. The existence of unexpected components is due to the necessity to know the shocks in trading activities, as it has a larger impact on the price changes than the expected component. Bessembinder and Seguin (1993), Ragunathan and Peker (1997), Watanabe (2001), and Boonvorachote and Lakmas (2016) employed the expected and unexpected components of open interest and trading volume to investigate the volatility of return in the currencies market, agricultural commodities market, stocks markets, and futures markets. However, no study has employed the mentioned method in the crude palm oil futures market. Hence, this study fills the research gap.

\section{Data Description}

The data used are daily settlement price, trading volume, and open interest of crude palm oil futures that traded on the Malaysia Derivatives Exchange (MDEX). The data were extracted from the Bursa Malaysia Derivatives website (www.bursamalaysia.com, accessed on 30 June 2020). The sample period for this study is from 1 January 2010 to 31 December 2019 , with the total observations amounting to 2583 . The settlement price, trading volume, and open interest for the spot-month contract, one-month contract, two-month contract, three-month contract, six-month contract, and nine-month contract are used to examine the volatility of return on the Malaysian Crude Palm Oil Futures.

The daily log return of Malaysian Crude Palm Oil Futures is calculated using the settlement prices on each contract. The trading volume and open interest are transformed to logarithm before the analysis. Trading volume and open interest are used to examine the volatility of return of crude palm oil futures.

The 50 days backward moving average method is used to ensure the time series is stationary for the trading volume and open interest (Fung and Patterson 1999). The formula of 50 days backward moving average trading volume and open interest respectively are described as follows:

$$
V o l_{t}=\frac{V o l_{t}}{\frac{1}{50} \sum_{k=1}^{50} V o l_{t-k}}
$$


where $\mathrm{Vol}_{t}$ is the volume at day $t$ and the denominator is the 50 days of backward moving average.

$$
\operatorname{OpIn}_{t}=\frac{O p \operatorname{In}_{t}}{\frac{1}{50} \sum_{k=1}^{50} O p \operatorname{In}_{t-k}}
$$

where $O p n_{t}$ is the open interest at day $t$ and the denominator is the 50 days of backward moving average.

Table 1 shows the descriptive statistics of the daily return, trading volume, and open interest used in this study. The spot-month contract has the highest mean return, while the six-month contract has the lowest mean return. The most volatile contracts are the spot-month contract and the two-month contract, providing a standard deviation of return of approximately $1.55 \%$. The least volatile contract is the nine-month contract, with a standard deviation of return of approximately 1.10\%. The kurtosis for all the contracts of return, trading volume, and open interest are greater than three except the trading volume for the one-month contract, in which the distribution of all contracts has a heavier tail; this is referred to as a leptokurtic distribution with the central peak of the distribution being lower and broader. The Jarque and Bera (1987) normality test shows that the distribution is significant for return, volume, and open interest for all the contracts except trading volume for the one-month contract. This shows that none of the return, volume, and open interest are normally distributed. Therefore, it is important to investigate the volatility of return affected by the trading volume and open interest due to high fluctuation. The ARCH test shows that the error terms for all month contracts have an ARCH effect. As the market is not stable or volatile, there is a need to use the GARCH model to examine the volatility of crude palm oil futures.

Table 1. Descriptive statistics of return, volume, and open interest.

\begin{tabular}{|c|c|c|c|c|c|c|}
\hline Contract & Mean & Standard Deviation & Skewness & Kurtosis & Jarque-Bera & $\mathrm{ARCH}$ \\
\hline \multicolumn{7}{|c|}{ Spot-month contract } \\
\hline Return & $7.65 \times 10^{-5}$ & 0.0154 & 0.2542 & 8.4494 & $3222.58^{* * *}$ & $22.66^{* * *}$ \\
\hline Volume & 2.2222 & 0.7157 & -1.1694 & 4.2624 & $759.90^{* * *}$ & $486.86^{* * *}$ \\
\hline Open interest & 3.3501 & 0.3773 & -0.9002 & 5.4708 & $1005.45^{* * *}$ & $1751.35^{* * *}$ \\
\hline \multicolumn{7}{|c|}{ One-month contract } \\
\hline Return & $7.32 \times 10^{-5}$ & 0.0153 & -0.0085 & 7.2986 & $1987.94^{* * *}$ & $63.65^{* * *}$ \\
\hline Volume & 3.4485 & 0.3199 & -0.0110 & 2.8592 & 2.19 & $355.18^{* * *}$ \\
\hline Open interest & 4.2275 & 0.2175 & -0.3410 & 3.4313 & $70.06^{* * *}$ & $1213.48^{* * *}$ \\
\hline \multicolumn{7}{|c|}{ Two-month contract } \\
\hline Return & $6.53 \times 10^{-5}$ & 0.0155 & -0.0317 & 7.5707 & $2247.99^{* * *}$ & $112.82^{* * *}$ \\
\hline Volume & 4.2257 & 0.1717 & -0.8161 & 4.1144 & $420.18^{* * *}$ & $911.99 * * *$ \\
\hline Open interest & 4.6091 & 0.1383 & -0.6320 & 3.7793 & $237.23^{* * *}$ & $1720.41^{* * *}$ \\
\hline \multicolumn{7}{|c|}{ Three-month contract } \\
\hline Return & $6.30 \times 10^{-5}$ & 0.0143 & -0.0227 & 6.6719 & $1450.76^{* * *}$ & $52.86^{* * *}$ \\
\hline Volume & 3.7273 & 0.2661 & -0.7084 & 3.8434 & $292.47^{* * *}$ & $589.03^{* * *}$ \\
\hline Open interest & 4.4050 & 0.1995 & -0.8539 & 4.3493 & $509.61^{* * *}$ & $1966.00^{* * *}$ \\
\hline \multicolumn{7}{|l|}{ Six-month contract } \\
\hline Return & $3.15 \times 10^{-5}$ & 0.0122 & -1.4216 & 48.5298 & $223885.80^{* * *}$ & 0.35 \\
\hline Volume & 2.9591 & 0.6406 & -1.4615 & 4.8755 & $1297.55^{* * *}$ & $1364.53^{* * *}$ \\
\hline Open interest & 4.1430 & 0.2969 & -1.0549 & 3.4529 & $500.94^{* * *}$ & $2508.54^{* * *}$ \\
\hline \multicolumn{7}{|c|}{ Nine-month contract } \\
\hline Return & $3.77 \times 10^{-5}$ & 0.0110 & -0.1395 & 22.4994 & $40914.44^{* * *}$ & $3.88^{* *}$ \\
\hline Volume & 2.4643 & 0.7416 & -0.8398 & 3.4275 & $323.13^{* * *}$ & $987.14^{* * *}$ \\
\hline Open interest & 3.8796 & 0.4183 & -0.9079 & 3.1130 & $356.08^{* * *}$ & $2240.36^{* * *}$ \\
\hline
\end{tabular}

Note: ${ }^{* * *},{ }^{* *}$ denotes the significance at the $1 \%$ and $5 \%$ level, respectively. 


\section{Methodology}

Expected and unexpected components of trading activity (trading volume and open interest).

This paper uses the autoregressive moving average (ARMA) process to partition the trading activity into expected and unexpected components. ARMA $(1,1)$ estimates the onestep-ahead forecast error of trading volume and open interest for all contracts. Both trading volume and open interest are partitioned into expected and unexpected components, in which the information shocks have been separated. The equation for the ARMA $(1,1)$ model can be stated as follows:

$$
y_{t}=\mu+\kappa_{1} y_{t-1}+\varepsilon_{t}+\delta_{1} \varepsilon_{t-1}
$$

Equation (1) shows that $y_{t-1}$ is the autoregressive term, $\varepsilon_{t-1}$ is the moving average term, and $\mu$ is a constant term. The formulation of the ARMA model assumes that there is no common root in the AR and MA operators. After the error term (unexpected component) of the trading volume and open interest are determined, the expected components are obtained as $y_{t}-\varepsilon_{t} ; y_{t}$ is the actual component and $\varepsilon_{t}$ is the unexpected component. The expected and unexpected components of trading volume and open interest are applied to the variance equation of the GARCH model to examine the volatility of return of crude palm oil prices.

\section{Generalized Autoregressive Conditional Heteroscedasticity, GARCH $(1,1)$}

Engle (1982) emphasized that the ARCH effects are to be tested before proceeding to the GARCH $(1,1)$ model. If a model has ARCH effects and the volatility is clustering, then the GARCH model will be applied to examine the volatility of the return. The past shocks, which are captured by the ARCH model, do not provide much information concerning the variance when the trading volume is considered (Bollerslev 1986). GARCH $(1,1)$ is applied in this study because it provides good forecasting on volatility (Andersen and Bollerslev 1998). Hansen and Lunde (2005) supported the forecasting volatility by using the GARCH $(1,1)$ model. They found that a good volatility model did not provide better prediction than the GARCH $(1,1)$ model. The GARCH $(1,1)$, which is equal to an infinite order of the ARCH model, showed that the effect of innovations on current volatility reduces over time. The GARCH $(1,1)$ is an alternative way to measure the higher order of the $\mathrm{ARCH}$ process.

Boonvorachote and Lakmas $(2016)$ applied the GARCH $(1,1)$ by using the expected and unexpected components of trading volume and open interest to the variance. This paper follows the same approach. The equation of the GARCH $(1,1)$ that is used can be expressed as:

$$
\begin{gathered}
r_{t}=a_{0}+a_{1} r_{t-1}+a_{2} \mu_{t-1}+\mu_{t}, \mu_{t}=\sigma_{t} \varepsilon_{t} \\
\sigma_{t}^{2}=\beta_{0}+\beta_{1} \mu_{t-1}^{2}+\beta_{2} \sigma_{t-1}^{2}+\beta_{3} E x V_{t *}+\beta_{4} U \operatorname{Uex} V_{t *}+\beta_{5} E_{\text {ExOI I* }}+\beta_{6} \text { UexOI I }_{t *}
\end{gathered}
$$

where $\mu_{t-1}^{2}$ is the ARCH term; $\sigma_{t-1}^{2}$ is the GARCH term; $E x V_{t}$ is the expected volume at day $t$; Uex $V_{t}$ is the unexpected volume at day $t ; E x O I_{t}$ is the expected open interest at day $t ; \mathrm{UexOI}_{t}$ is the unexpected open interest at day $t$; and $\varepsilon_{t}$ is the residual, which is assumed to be an independent, identically distributed random variable. To examine the contemporaneous relation between the volatility of return and trading activities suggested by $\mathrm{MDH}, t^{*}$ is assumed to be the period $\mathrm{t}$ for examining the contemporaneous relation. On the other hand, we assume $t^{*}$ to be from period $t-1$ to period $t-5$ for investigating the lead-lag relationship between the volatility of return and trading activities. We choose five days of lag because we are interested to know the trading activities to determine which day of the week has the largest effect on the volatility of return.

\section{Empirical Results and Discussion}

Table 2 presents the results of Augmented Dickey-Fuller (ADF) and Elliott-RothenbergStock (ERS) unit root tests for the daily returns, volume, and open interest for all month contracts. The presence of the unit root is rejected, and all series are stationary for all 
contracts in the ADF unit root test. The ERS unit root test also shows similar result (except three-month contracts for volume).

Table 2. ADF and ERS unit root.

\begin{tabular}{|c|c|c|c|c|}
\hline \multirow[t]{2}{*}{ Variables } & \multicolumn{4}{|c|}{ Test Statistic } \\
\hline & $\tau_{\alpha}$ & $\tau_{\beta}$ & $\phi_{\alpha}$ & $\phi_{\beta}$ \\
\hline \multicolumn{5}{|l|}{ A: Level } \\
\hline \multicolumn{5}{|c|}{ Spot-month Contract: } \\
\hline Return & $-51.6071^{* * *}$ & $-51.6023^{* * *}$ & $-2.0612 * *$ & $-3.6981^{* * *}$ \\
\hline Volume & $-4.9018 * * *$ & $-5.2917 * * *$ & $-4.8337 * * *$ & $-5.1250^{* * *}$ \\
\hline Open interest & $-6.1592 * * *$ & $-6.2059 * * *$ & $-6.1609 * * *$ & $-6.1616^{* * *}$ \\
\hline \multicolumn{5}{|c|}{ One-month Contract: } \\
\hline Return & $-54.0315^{* * *}$ & $-54.0275^{* * *}$ & $-2.9311^{* * *}$ & $-5.1289 * * *$ \\
\hline Volume & $-5.0250 * * *$ & $-6.0812 * * *$ & -1.5434 & $-3.6473^{* * *}$ \\
\hline Open interest & $-5.4336 * * *$ & $-6.2169 * * *$ & $-3.6843^{* * *}$ & $-6.1620^{* * *}$ \\
\hline \multicolumn{5}{|c|}{ Two-month Contract: } \\
\hline Return & $-56.3000 * * *$ & $-56.2962 * * *$ & $-5.0729 * * *$ & $-34.4429^{* * *}$ \\
\hline Volume & $-6.4385^{* * *}$ & $-8.0034^{* * *}$ & -1.5566 & $-4.1172^{* * *}$ \\
\hline Open interest & $-6.5373^{* * *}$ & $-8.8007^{* * *}$ & $-2.8764^{* * *}$ & $-7.7125^{* * *}$ \\
\hline \multicolumn{5}{|c|}{ Three-month Contract: } \\
\hline Return & $-54.6713^{* * *}$ & $-54.6686^{* * *}$ & $-2.0021^{* *}$ & $-3.7184^{* * *}$ \\
\hline Volume & $-3.9425^{* * *}$ & $-17.4800^{* * *}$ & -0.6096 & -2.2942 \\
\hline Open interest & $-9.2465^{* * *}$ & $-12.1841^{* * *}$ & $-3.4536^{* * *}$ & $-10.2737^{* * *}$ \\
\hline \multicolumn{5}{|c|}{ Six-month Contract: } \\
\hline Return & $-52.6216^{* * *}$ & $-52.6154^{* * *}$ & $-5.4329 * * *$ & $-49.2403^{* * *}$ \\
\hline Volume & $-5.3530 * * *$ & $-6.8671^{* * *}$ & -1.6059 & $-4.4064^{* * *}$ \\
\hline Open interest & $-3.8571^{* * *}$ & $-4.5941^{* * *}$ & $-2.7850^{* * *}$ & $-4.586^{* * *}$ \\
\hline \multicolumn{5}{|c|}{ Nine-month Contract: } \\
\hline Return & $-53.8715^{* * *}$ & $-53.8617^{* * *}$ & $-53.8777^{* * *}$ & $-51.3344^{* * *}$ \\
\hline Volume & $-7.1460 * * *$ & $-8.0280^{* * *}$ & $-2.5343^{* *}$ & $-5.7945^{* * *}$ \\
\hline Open interest & $-6.2668^{* * *}$ & $-6.6910 * * *$ & $-2.7567^{* * *}$ & $-6.6709^{* * *}$ \\
\hline
\end{tabular}

Note: The $\tau$ statistic is for the ADF unit root test and the $\phi$ statistic is for the ERS unit root test. The subscript $\alpha$ in the model allows the intercept term and $\beta$ allows for a trend and intercept. Asterisks $\left({ }^{* *},{ }^{* *}\right)$ show statistical significance at the $1 \%$ and $5 \%$ level, respectively.

Table 3 shows that the autoregressive, AR(1), for trading volume and open interest of all contracts are positive and significant at $1 \%$. The results indicate that immediate preceding of the volume and open interest can predict the current value. On the other hand, the moving average, $\mathrm{MA}(1)$ for the trading volume of the contracts is negative and significant. Whereas the MA(1) for open interest is positive and significant for the spotmonth contract and one-month contract but negative and significant for the two-month contract. The negative magnitude of the trading volume shows that there are negative spikes that affect the future volume. The magnitude for open interest is positive, except for the two-month contract, which shows an opposite outcome compared to the trading volume. Through the ARMA process, we partition the trading volume and open interest into expected and unexpected components. 
Table 3. Autoregressive and Moving Average Test (ARMA 1,1).

\begin{tabular}{|c|c|c|c|c|}
\hline \multirow[t]{2}{*}{ Variables } & \multicolumn{4}{|c|}{ Test Statistics } \\
\hline & $\begin{array}{c}\text { Autoregressive } \\
\text { (1) }\end{array}$ & $\begin{array}{c}\text { Moving } \\
\text { Average (1) }\end{array}$ & $\begin{array}{l}\text { Akaike Info } \\
\text { Criterion }\end{array}$ & $\begin{array}{l}\text { Schwarz } \\
\text { Criterion }\end{array}$ \\
\hline \multicolumn{5}{|l|}{ Spot-month Contract } \\
\hline Trading Volume & $\begin{array}{c}0.6384^{* * *} \\
{[0.0282]}\end{array}$ & $\begin{array}{c}-0.1468^{* * *} \\
{[0.0363]}\end{array}$ & -7.524318 & -7.517404 \\
\hline Open Interest & $\begin{array}{c}0.7120 * * * \\
{[0.0182]}\end{array}$ & $\begin{array}{c}0.1258^{* * *} \\
{[0.0257]}\end{array}$ & -10.2792 & -10.27232 \\
\hline \multicolumn{5}{|l|}{ One-month Contract } \\
\hline Trading Volume & $\begin{array}{c}0.6255^{* * *} \\
{[0.0291]}\end{array}$ & $\begin{array}{c}-0.1386^{* * *} \\
{[0.0369]}\end{array}$ & -10.13442 & -10.1275 \\
\hline Open Interest & $\begin{array}{c}0.6901 * * * \\
{[0.0201]}\end{array}$ & $\begin{array}{l}0.0501 * \\
{[0.0278]}\end{array}$ & -11.7516 & -11.7447 \\
\hline \multicolumn{5}{|l|}{ Two-month Contract } \\
\hline Trading Volume & $\begin{array}{c}0.7456 * * * \\
{[0.0238]} \\
\end{array}$ & $\begin{array}{c}-0.3224^{* * *} \\
{[0.0338]}\end{array}$ & -12.35233 & -12.34542 \\
\hline Open Interest & $\begin{array}{c}0.8868^{* * *} \\
{[0.0108]}\end{array}$ & $\begin{array}{c}-0.1366^{* * *} \\
{[0.0231]}\end{array}$ & -14.4538 & -14.4469 \\
\hline \multicolumn{5}{|c|}{ Three-month Contract } \\
\hline Trading Volume & $\begin{array}{c}0.6690^{* * *} \\
{[0.0294]}\end{array}$ & $\begin{array}{c}-0.2499 * * * \\
{[0.0383]}\end{array}$ & -10.97702 & -10.9701 \\
\hline Open Interest & $\begin{array}{c}0.8488 * * * \\
{[0.0124]}\end{array}$ & $\begin{array}{c}0.0055 \\
{[0.0234]}\end{array}$ & -13.3459 & -13.339 \\
\hline \multicolumn{5}{|l|}{ Six-month Contract } \\
\hline Trading Volume & $\begin{array}{c}0.8880 * * * \\
{[0.0125]}\end{array}$ & $\begin{array}{c}-0.4444^{* * *} \\
{[0.0243]}\end{array}$ & -9.304658 & -9.297745 \\
\hline Open Interest & $\begin{array}{c}0.9510 * * * \\
{[0.0065]}\end{array}$ & $\begin{array}{c}0.0047 \\
{[0.0209]}\end{array}$ & -14.0261 & -14.0191 \\
\hline \multicolumn{5}{|l|}{ Nine-month Contract } \\
\hline Trading Volume & $\begin{array}{c}0.8907^{* * *} \\
{[0.0123]}\end{array}$ & $\begin{array}{c}-0.4501^{* * *} \\
{[0.0241]}\end{array}$ & -8.15749 & -8.150576 \\
\hline Open Interest & $\begin{array}{c}0.9245^{* * *} \\
{[0.0082]}\end{array}$ & $\begin{array}{c}0.0092 \\
{[0.0215]}\end{array}$ & -12.2498 & -12.2428 \\
\hline
\end{tabular}

Note: The Autoregressive (AR) and Moving Average (MA) are significant when the $p$-value is less than $1 \%, 5 \%$, and $10 \%$. $\left.{ }^{* * *} p<0.01,{ }^{*} p<0.10\right)$. The standard errors are in square brackets.

\subsection{Testing on Contemporary Effect of Trading Activity and Volatility of Return}

Table 4 portrays the estimation results of the GARCH $(1,1)$ model with ARMA $(1,1)$ for the volatility of return for crude palm oil futures. The summation of the estimated coefficient on the variance equation for $\beta_{1}$ and $\beta_{2}$, which is less than one, is required to have a mean reverting variance process (Engle 2001). Table 4 shows that the summation of the estimated coefficients $\beta_{1}+\beta_{2}$ is less than one and that the parameters of $\beta_{1}$ and $\beta_{2}$ are positive. Hence, the results fulfilled the priori expectation of the GARCH $(1,1)$ model.

The parameter $\beta_{1}$ is a measure of the current innovations that have a significant impact on the current volatility of return. On the other hand, the parameter $\beta_{2}$ can be described as the impact of past shocks on the current volatility of return for the crude palm oil price. Based on Table 4 , both parameters, $\beta_{1}$ and $\beta_{2}$, are significant to the volatility of return for all contracts except the two-month contract. The results imply that the current and past news have a significant impact on the volatility of return for Malaysian Crude Palm Oil 
Futures. Furthermore, $\beta_{2}$ is larger than $\beta_{1}$, showing that the impact of past news creates a larger impact on the current volatility of returns than the current news.

Table 4. Estimation Results of GARCH $(1,1)$ for Malaysian Crude Palm Oil Futures.

\begin{tabular}{|c|c|c|c|c|c|}
\hline & $\begin{array}{l}\text { Spot-Month } \\
\text { Contract }\end{array}$ & $\begin{array}{l}\text { One-Month } \\
\text { Contract }\end{array}$ & $\begin{array}{l}\text { Two-Month } \\
\text { Contract }\end{array}$ & $\begin{array}{l}\text { Three-Month } \\
\text { Contract }\end{array}$ & $\begin{array}{l}\text { Nine-Month } \\
\text { Contract }\end{array}$ \\
\hline \multicolumn{6}{|c|}{ Mean Equation } \\
\hline \multirow{2}{*}{$a_{0}$} & 0.0000 & 0.0000 & 0.0002 & 0.0001 & 0.0000 \\
\hline & {$[0.0520]$} & {$[-0.0221]$} & {$[0.5076]$} & {$[0.2968]$} & [0.1103] \\
\hline \multirow{2}{*}{$r_{t-1}$} & $0.7749^{* * *}$ & $0.7364^{* * *}$ & -0.1025 & -0.0660 & 0.0016 \\
\hline & [2.9490] & [3.5572] & {$[-0.6531]$} & {$[-0.2310]$} & [0.0006] \\
\hline \multirow{2}{*}{$\mu_{t-1}$} & $-0.7637^{* * *}$ & $-0.7504^{* * *}$ & 0.0044 & 0.0068 & 0.0063 \\
\hline & {$[-2.8419]$} & {$[-3.7073]$} & {$[0.0278]$} & {$[0.0236]$} & [0.0025] \\
\hline \multicolumn{6}{|c|}{ Variance Equation } \\
\hline \multirow[t]{2}{*}{$\beta_{0}$} & $0.0001^{* * *}$ & $0.0002 * * *$ & $0.0002^{* * *}$ & $0.0002^{* *}$ & $0.0001^{* * *}$ \\
\hline & {$[9.2314]$} & [6.0565] & [13.0156] & {$[2.2261]$} & {$[8.7326]$} \\
\hline \multirow[t]{2}{*}{$\mu_{t-1}^{2}$} & $0.0514^{* * *}$ & $0.0591^{* * *}$ & 0.0014 & $0.0391^{* * *}$ & $0.1076^{* * *}$ \\
\hline & [11.4604] & [11.9570] & [0.4353] & [45.1211] & [15.9924] \\
\hline \multirow{2}{*}{$\sigma_{t-1}^{2}$} & $0.9246^{* * *}$ & $0.9158^{* * *}$ & $0.5811^{* * *}$ & $0.5921^{* * *}$ & $0.6808^{* * *}$ \\
\hline & [156.3793] & [141.7922] & [8.9998] & [13.8198] & [86.2419] \\
\hline \multirow[t]{2}{*}{$E x V_{t}$} & -0.0005 & $-0.0084^{* * *}$ & -0.0022 & -0.0023 & $0.0010^{* * *}$ \\
\hline & {$[-0.7906]$} & {$[-4.5071]$} & {$[-0.3695]$} & {$[-0.6207]$} & {$[19.6501]$} \\
\hline \multirow[t]{2}{*}{ Uex $V_{t}$} & 0.0010 & $0.0145^{* * *}$ & $0.0635^{* * *}$ & $0.0335^{* * *}$ & $0.0045^{* * *}$ \\
\hline & [1.4515] & [7.6383] & [27.4299] & [18.7010] & [56.1475] \\
\hline \multirow[t]{2}{*}{$\mathrm{ExOI}_{t}$} & $-0.0059 * * *$ & -0.0002 & -0.0023 & -0.0023 & $-0.0029^{* * *}$ \\
\hline & {$[-6.4767]$} & {$[-0.1180]$} & {$[-0.3763]$} & {$[-0.5392]$} & {$[-7.7406]$} \\
\hline \multirow[t]{2}{*}{ UexOIt } & $0.0141^{* * *}$ & $-0.0113^{* * *}$ & $0.0758^{* * *}$ & $-0.0907^{* * *}$ & $-0.0033^{* * *}$ \\
\hline & [5.7209] & {$[-2.8184]$} & [8.1447] & {$[-9.7606]$} & {$[-7.0535]$} \\
\hline $\operatorname{adj} R^{2}$ & -0.0012 & 0.0010 & 0.0093 & 0.0041 & -0.0018 \\
\hline AIC & -5.6327 & -5.6578 & -5.5335 & -5.7304 & -6.2842 \\
\hline$S C$ & -5.6097 & -5.6347 & -5.5104 & -5.7074 & -6.2612 \\
\hline
\end{tabular}

Note: The coefficients are significant when $p$-value is less than $1 \%, 5 \%$, and $10 \% .\left({ }^{* * *} p<0.01,{ }^{* *} p<0.05\right)$. The $\mathrm{t}$-statistics are in square brackets.

The sum of the parameters $\left(\beta_{1}+\beta_{2}\right)$ is the measurement for the degree of the volatility persistence shocks. Volatility persistence shows that the volatility of return in future is affected by the current and past volatility. The parameters $\left(\beta_{1}+\beta_{2}\right)$ for crude palm oil return volatility for the spot-month contract, one-month contract, two-month contract, three-month contract, and nine-month contract are $0.9760,0.9749,0.5825,0.6312$, and 0.7884 , respectively. The degree of volatility persistence shocks of return, which is known as the reverting process, for crude palm oil futures for the spot-month contract and one-month contract are very close to one, thereby showing that the volatility shocks are persistent. There is no explosive or long-term memory in the conditional variance for those contracts.

The results show that the coefficient of the expected trading volume is only significant for the one-month contract and the nine-month contract. The negative coefficient of expected trading volume indicates that the expected trading volume produces a negative effect on the risk of the crude palm oil futures for the one-month contract. When the expected trading volume increases, the volatility of return for the crude palm oil futures decreases. However, the coefficient of expected trading volume for the nine-month contract is positive, which indicates that there is a positive relation between expected trading volume and volatility of return. The positive relation is supported by the MDH.

On the other hand, the coefficient of the unexpected trading volume is positive and significant to the volatility of return for all contracts, except the spot-month contract. The expected and unexpected volume have heterogeneous effects on volatility. The estimated coefficients of the unexpected volume are uniformly higher than those associated with the expected volume. When the unexpected trading volume increases, the risk of the return also increases. Furthermore, the magnitude of the unexpected trading volume for 
all contracts is greater than the expected trading volume. This finding is consistent with Bessembinder and Seguin (1993), who found that the unexpected trading volume creates a larger effect than the expected trading volume on the volatility of return.

The coefficient of the expected open interest is negative and significant to the volatility of return for the spot-month contract and nine-month contract. Nevertheless, the coefficient of unexpected open interest is also negative and is significant for the one-month contract, three-month contract, and nine-month contract. An increment in the open interest, which would result in the momentum of the money flow, will lead investors to assume that the market is in bullish trend. Therefore, the risk of the crude palm oil futures will decrease. These results are contradictory to the MDH. However, the coefficient of unexpected open interest for the spot-month contract and two-month contract is positive and significant, which is in line with the MDH. The magnitude for the unexpected component of open interest is greater than those for the expected component. The unexpected components create a larger effect on the volatility of return of the crude palm oil futures.

As a robustness check, EGARCH model estimation is performed, and the estimation results are reported in Table 5 . We find that there is a leverage effect on the volatility for all contracts, except the-nine-month contract. In general, the result is consistent with the GARCH estimation in Table 5.

$$
r_{t}=a_{0}+a_{1} r_{t-1}+a_{2} \mu_{t-1}+\mu_{t}, \mu_{t}=\sigma_{t} \varepsilon_{t}
$$

$\ln \left(\sigma_{t}^{2}\right)=\beta_{0}+\alpha \ln \left(\sigma_{t-1}^{2}\right)+\beta\left|\frac{\mu_{t-1}^{2}}{\sqrt{\sigma_{t-1}^{2}}}\right|+\gamma \frac{\mu_{t-1}^{2}}{\sqrt{\sigma_{t-1}^{2}}}+\beta_{3} E x V_{t *}+\beta_{4} U \operatorname{ex} V_{t *}+\beta_{5} E x O I_{t *}+\beta_{6}$UexOI $_{t *}$

Table 5. Estimation Results of EGARCH $(1,1)$ for Malaysian Crude Palm Oil Futures.

\begin{tabular}{|c|c|c|c|c|c|}
\hline & $\begin{array}{l}\text { Spot-Month } \\
\text { Contract }\end{array}$ & $\begin{array}{l}\text { One-Month } \\
\text { Contract }\end{array}$ & $\begin{array}{l}\text { Two-Month } \\
\text { Contract }\end{array}$ & $\begin{array}{c}\text { Three-Month } \\
\text { Contract }\end{array}$ & $\begin{array}{c}\text { Nine-Month } \\
\text { Contract }\end{array}$ \\
\hline \multicolumn{6}{|c|}{ Mean Equation } \\
\hline \multirow[t]{2}{*}{$a_{0}$} & -0.0001 & 0.0000 & 0.0000 & 0.0001 & 0.0002 \\
\hline & {$[0.0003]$} & [0.0003] & {$[0.0002]$} & {$[0.0002]$} & {$[0.0002]$} \\
\hline \multirow{2}{*}{$r_{t-1}$} & $0.7646 * * *$ & $0.7338 * * *$ & $0.6261 * * *$ & $0.6739 * * *$ & $0.5812 *$ \\
\hline & {$[0.2170]$} & {$[0.1979]$} & {$[0.2249]$} & {$[0.1700]$} & [0.3184] \\
\hline \multirow{2}{*}{$\mu_{t-1}$} & $-0.7524^{* * *}$ & $-0.7511^{* * *}$ & $-0.6600^{* * *}$ & $-0.6984^{* * *}$ & $-0.6155^{* *}$ \\
\hline & [0.2224] & [0.1922] & {$[0.2180]$} & {$[0.1654]$} & {$[0.3022]$} \\
\hline \multicolumn{6}{|c|}{ Variance Equation } \\
\hline \multirow{2}{*}{$\beta_{0}$} & $0.4278 * * *$ & $0.8474^{* * *}$ & $4.8265 * * *$ & $2.1457 * * *$ & $-3.0079 * * *$ \\
\hline & {$[0.0625]$} & {$[0.2074]$} & {$[0.3856]$} & {$[0.3191]$} & {$[0.3062]$} \\
\hline \multirow[t]{2}{*}{$\beta$} & $0.1151^{* * *}$ & $0.1281 * * *$ & $0.1297 * * *$ & $0.1444^{* * *}$ & $0.1817^{* * *}$ \\
\hline & {$[0.0087]$} & [0.0093] & [0.0085] & {$[0.0115]$} & {$[0.0216]$} \\
\hline \multirow[t]{2}{*}{$\mathrm{y}$} & $-0.0414^{* * *}$ & $-0.0329^{* * *}$ & $-0.0349^{* * *}$ & $-0.0280 * * *$ & -0.0036 \\
\hline & [0.0063] & {$[0.0070]$} & [0.0067] & {$[0.0072]$} & [0.0162] \\
\hline \multirow[t]{2}{*}{$\alpha$} & $0.9857^{* * *}$ & $0.9867 * * *$ & $0.9890^{* * *}$ & $0.9855^{* * *}$ & $0.6327^{* * *}$ \\
\hline & {$[0.0027]$} & {$[0.0032]$} & {$[0.0029]$} & {$[0.0037]$} & {$[0.0380]$} \\
\hline \multirow[t]{2}{*}{$E x V_{t}$} & $-0.0598^{* *}$ & $-0.8122^{* * *}$ & $-2.4988^{* * *}$ & $-1.6062 * * *$ & $0.1748^{* * *}$ \\
\hline & [0.0299] & {$[0.1164]$} & [0.1803] & {$[0.1758]$} & [0.0294] \\
\hline \multirow[t]{2}{*}{$U e x V_{t}$} & $0.1087^{* * *}$ & $1.3793^{* * *}$ & $4.6476^{* * *}$ & $2.2252 * * *$ & $0.3678^{* * *}$ \\
\hline & [0.0357] & [0.1433] & {$[0.2066]$} & [0.1980] & {$[0.0195]$} \\
\hline \multirow[t]{2}{*}{$E x O I_{t}$} & $-0.2548^{* * *}$ & 0.2850 * & -0.0067 & $0.4186^{* * *}$ & $-0.3854^{* * *}$ \\
\hline & [0.0465] & [0.1615] & [0.1130] & [0.1010] & [0.0845] \\
\hline \multirow[t]{2}{*}{ UexOI } & $0.6178^{* * *}$ & $-1.4364^{* * *}$ & 0.0888 & $-2.9094^{* * *}$ & $-0.8428^{* * *}$ \\
\hline & [0.1298] & [0.2963] & [0.5622] & [0.4850] & {$[0.0716]$} \\
\hline AIC & -5.6329 & -5.6503 & -5.6772 & -5.7920 & -6.2308 \\
\hline$S C$ & -5.6076 & -5.6250 & -5.6518 & -5.7666 & -6.2054 \\
\hline
\end{tabular}

Note: The coefficients are significant when $p$-value is less than $1 \%, 5 \%$, and $10 \%$. $\left.{ }^{* * *} p<0.01,^{* *} p<0.05,{ }^{*} p<0.10\right)$ The t-statistics are in square brackets. The coefficients of $\alpha$ and $\beta$ are the same as $\beta_{2}$ and $\beta_{1}$ in the GARCH model in Equation (2), which are the arch and GARCH terms. The coefficient $\gamma$ shows the leverage effect of the volatility. 


\subsection{Testing on Lag Effect of Trading Activity and Volatility of Return}

Table 6 shows the relationship between the lagged effect of the expected and unexpected components for trading activities and the volatility of return of the crude palm oil futures. The results show that the coefficient for the expected trading volume with lagged 1 is significant and positive for the spot-month contract, two-month contract, and three-month contract. Besides that, the expected trading volume lagged 2 days for all the coefficients, which is significant and positive except for the spot-month contract. Furthermore, the expected trading volume coefficient for lagged 3 days is significant and positive for the three-month contract and nine-month contract. However, the expected trading volume coefficient for lagged 4 and 5 days is only significant and positive for the nine-month contract and lagged 5 days for the spot-month contract. All the positive relations between the lagged of expected trading volume and the volatility of return support the SIAH.

Table 6. Estimation Results of GARCH $(1,1)$ for Malaysian Crude Palm Oil Futures.

\begin{tabular}{|c|c|c|c|c|c|}
\hline & $\begin{array}{l}\text { Spot-Month } \\
\text { Contract }\end{array}$ & $\begin{array}{l}\text { One-Month } \\
\text { Contract }\end{array}$ & $\begin{array}{l}\text { Two-Month } \\
\text { Contract }\end{array}$ & $\begin{array}{c}\text { Three-Month } \\
\text { Contract }\end{array}$ & $\begin{array}{l}\text { Nine-Month } \\
\text { Contract }\end{array}$ \\
\hline \multicolumn{6}{|c|}{ Period $\mathrm{t}-1$} \\
\hline$E x V_{t-1}$ & $\begin{array}{l}0.0015^{* *} \\
{[2.4988]}\end{array}$ & $\begin{array}{c}0.0021 \\
{[0.9277]}\end{array}$ & $\begin{array}{c}0.0109 * * * \\
{[2.7429]}\end{array}$ & $\begin{array}{l}0.0015^{* *} \\
{[2.4988]}\end{array}$ & $\begin{array}{c}0.0001 \\
{[0.9540]}\end{array}$ \\
\hline$U e x V_{t-1}$ & $\begin{array}{c}-0.0019 * * * \\
{[-2.9845]}\end{array}$ & $\begin{array}{c}0.0003 \\
{[0.1271]}\end{array}$ & $\begin{array}{l}-0.0099 * \\
{[-1.9216]}\end{array}$ & $\begin{array}{c}-0.0019 * * * \\
{[-2.9845]}\end{array}$ & $\begin{array}{c}0.0024 * * * \\
{[5.7130]}\end{array}$ \\
\hline$E x O I_{t-1}$ & $\begin{array}{c}0.0011 \\
{[1.3198]}\end{array}$ & $\begin{array}{c}0.0013 \\
{[0.4334]}\end{array}$ & $\begin{array}{l}-0.0013 \\
{[-0.4053]}\end{array}$ & $\begin{array}{c}0.0011 \\
{[1.3198]}\end{array}$ & $\begin{array}{l}-0.0014 \\
{[-2.3938]}\end{array}$ \\
\hline UexOI $I_{t-1}$ & $\begin{array}{c}-0.0060 * * * \\
{[-2.6522]}\end{array}$ & $\begin{array}{l}-0.0144 * * \\
{[-2.3882]}\end{array}$ & $\begin{array}{c}0.0008 \\
{[0.0554]}\end{array}$ & $\begin{array}{c}-0.0060 * * * \\
{[-2.6522]}\end{array}$ & $\begin{array}{c}-0.0043 \\
{[-0.7991]}\end{array}$ \\
\hline \multicolumn{6}{|c|}{ Period t-2 } \\
\hline$E x V_{t-2}$ & $\begin{array}{l}-0.0005 \\
{[0.0004]}\end{array}$ & $\begin{array}{l}0.0060 * * \\
{[2.5572]}\end{array}$ & $\begin{array}{c}0.0100 * * * \\
{[2.6303]}\end{array}$ & $\begin{array}{c}0.0074^{* * *} \\
{[2.9129]}\end{array}$ & $\begin{array}{c}0.0007^{* * *} \\
{[7.8277]}\end{array}$ \\
\hline$U e x V_{t-2}$ & $\begin{array}{c}0.0003 \\
{[0.0005]}\end{array}$ & $\begin{array}{c}-0.0045 \\
{[-1.5348]}\end{array}$ & $\begin{array}{c}-0.0061 \\
{[-1.4452]}\end{array}$ & $\begin{array}{l}-0.0069 * * \\
{[-2.5211]}\end{array}$ & $\begin{array}{c}-0.0015^{* * *} \\
{[-4.4444]}\end{array}$ \\
\hline$E x O I_{t-2}$ & $\begin{array}{l}0.0033^{* * *} \\
{[0.0007]}\end{array}$ & $\begin{array}{l}-0.0001 \\
{[-0.0185]}\end{array}$ & $\begin{array}{l}-0.0034 \\
{[-1.0760]}\end{array}$ & $\begin{array}{l}-0.0038 * * \\
{[-1.9853]}\end{array}$ & $\begin{array}{c}-0.0019 * * * \\
{[-3.7372]}\end{array}$ \\
\hline UexOIt-2 & $\begin{array}{c}-0.0105^{* * *} \\
{[0.0019]}\end{array}$ & $\begin{array}{l}-0.0094 \\
{[-1.5762]}\end{array}$ & $\begin{array}{c}0.0099 \\
{[0.8327]}\end{array}$ & $\begin{array}{l}0.0163^{* *} \\
{[2.1689]}\end{array}$ & $\begin{array}{l}0.0074 * * \\
{[2.0639]}\end{array}$ \\
\hline \multicolumn{6}{|c|}{ Period $\mathrm{t}-3$} \\
\hline$E x V_{t-3}$ & $\begin{array}{c}0.0005 \\
{[0.9596]}\end{array}$ & $\begin{array}{c}0.0016 \\
{[0.7385]}\end{array}$ & $\begin{array}{c}0.0012 \\
{[0.3020]}\end{array}$ & $\begin{array}{l}0.0060 * * \\
{[2.3602]}\end{array}$ & $\begin{array}{c}0.0008^{* * *} \\
{[8.1911]}\end{array}$ \\
\hline$U e x V_{t-3}$ & $\begin{array}{l}-0.0006 \\
{[-1.1715]}\end{array}$ & $\begin{array}{c}0.0020 \\
{[0.7430]}\end{array}$ & $\begin{array}{c}0.0079 \\
{[1.5693]}\end{array}$ & $\begin{array}{l}-0.0047^{*} \\
{[-1.6538]}\end{array}$ & $\begin{array}{c}-0.0019 * * * \\
{[-4.5102]}\end{array}$ \\
\hline$E x O I_{t-3}$ & $\begin{array}{l}0.0021^{* *} \\
{[2.4690]}\end{array}$ & $\begin{array}{l}0.0051 * \\
{[1.7313]}\end{array}$ & $\begin{array}{l}-0.0048 \\
{[-1.5791]}\end{array}$ & $\begin{array}{l}-0.0025 \\
{[-1.3241]}\end{array}$ & $\begin{array}{c}-0.0024^{* * *} \\
{[-4.6811]}\end{array}$ \\
\hline UexOIt-3 & $\begin{array}{c}-0.0066^{* * *} \\
{[-3.3669]}\end{array}$ & $\begin{array}{c}-0.0191 * * * \\
{[-3.0815]}\end{array}$ & $\begin{array}{c}0.0164 \\
{[1.4056]}\end{array}$ & $\begin{array}{c}0.0082 \\
{[1.0385]}\end{array}$ & $\begin{array}{l}0.0077 * \\
{[1.8977]}\end{array}$ \\
\hline \multicolumn{6}{|c|}{ Period t-4 } \\
\hline$E x V_{t-4}$ & $\begin{array}{l}-0.0006 \\
{[-1.2239]}\end{array}$ & $\begin{array}{l}-0.0006 \\
{[-0.2074]}\end{array}$ & $\begin{array}{c}-0.0032 \\
{[-0.7625]}\end{array}$ & $\begin{array}{c}0.0000 \\
{[-0.0037]}\end{array}$ & $\begin{array}{c}0.0008^{* * *} \\
{[7.5915]}\end{array}$ \\
\hline$U e x V_{t-4}$ & $\begin{array}{l}0.0010 * \\
{[1.7005]}\end{array}$ & $\begin{array}{l}0.0051 * \\
{[1.6543]}\end{array}$ & $\begin{array}{c}0.0347^{* * *} \\
{[8.4970]}\end{array}$ & $\begin{array}{c}0.0020 \\
{[0.6143]}\end{array}$ & $\begin{array}{c}-0.0018 * * * \\
{[-4.3272]}\end{array}$ \\
\hline$E x O I_{t-4}$ & $\begin{array}{l}0.0018^{* *} \\
{[2.3772]}\end{array}$ & $\begin{array}{c}0.0024 \\
{[0.7154]}\end{array}$ & $\begin{array}{l}-0.0033 \\
{[-0.7173]}\end{array}$ & $\begin{array}{c}0.0014 \\
{[0.8201]}\end{array}$ & $\begin{array}{c}-0.0007 \\
{[-1.4537]}\end{array}$ \\
\hline$U_{e x O I} I_{t-4}$ & $\begin{array}{c}-0.0059 * * * \\
{[-3.0711]}\end{array}$ & $\begin{array}{l}-0.0126^{*} \\
{[-1.8478]}\end{array}$ & $\begin{array}{c}0.0626^{* * *} \\
{[3.9133]}\end{array}$ & $\begin{array}{l}-0.0139 * \\
{[-1.6985]}\end{array}$ & $\begin{array}{c}-0.0052 \\
{[-1.1296]}\end{array}$ \\
\hline \multicolumn{6}{|c|}{ Period $\mathrm{t}-5$} \\
\hline$E x V_{t-5}$ & $\begin{array}{l}0.0011 * \\
{[1.8799]}\end{array}$ & $\begin{array}{c}0.0007 \\
{[0.4358]}\end{array}$ & $\begin{array}{c}-0.0039 \\
{[-1.0409]}\end{array}$ & $\begin{array}{c}0.0040 \\
{[1.4182]}\end{array}$ & $\begin{array}{c}0.0006^{* * *} \\
{[5.4937]}\end{array}$ \\
\hline$U e x V_{t-5}$ & $\begin{array}{l}-0.0010 * \\
{[-1.8098]}\end{array}$ & $\begin{array}{c}0.0028 \\
{[1.4208]}\end{array}$ & $\begin{array}{l}0.0116^{* *} \\
{[2.2473]}\end{array}$ & $\begin{array}{c}-0.0025 \\
{[-0.7851]}\end{array}$ & $\begin{array}{c}-0.0003 \\
{[-0.7192]}\end{array}$ \\
\hline$E x O I_{t-5}$ & $\begin{array}{l}-0.0008 \\
{[-0.9698]}\end{array}$ & $\begin{array}{c}0.0036 \\
{[1.3335]}\end{array}$ & $\begin{array}{c}-0.0013 \\
{[-0.4000]}\end{array}$ & $\begin{array}{c}0.0015 \\
{[0.8795]}\end{array}$ & $\begin{array}{c}-0.0003 \\
{[-0.5893]}\end{array}$ \\
\hline UexOI $I_{t-5}$ & $\begin{array}{c}0.0017 \\
{[0.8732]}\end{array}$ & $\begin{array}{l}-0.0133^{* *} \\
{[-2.4299]}\end{array}$ & $\begin{array}{l}-0.0145 \\
{[-1.0213]}\end{array}$ & $\begin{array}{c}-0.0127 \\
{[-1.5807]}\end{array}$ & $\begin{array}{l}-0.0089 * * \\
{[-1.9904]}\end{array}$ \\
\hline
\end{tabular}

Note: The coefficients of the variables are significant when $p$-value is less than $1 \%, 5 \%$, and $10 \%$. $\left(^{* * *} p<0.01\right.$ ** $p<0.05, * p<0.10)$. The t-statistics are in square brackets. 
Most of the coefficients of unexpected trading volume are significant and negative for lagged 1 to 3 days for the spot-month contract, two-month contract, and three-month contract. However, the sign changed for the lagged 4 days. This means that the unexpected trading volume is disseminated to the trading after 3 days. The coefficient of unexpected trading volume is only significant and positive for the nine-month contract lagged 1 days but significant and negative in the lagged 2 to 4 days.

The coefficient of expected open interest is significant and positive for lagged 3 to 4 days for the spot-month contract. This shows that traders receive information of expected open interest after 3 days in the spot-month contract. However, the expected open interest coefficient is significant and positive for only lagged 3 days for the one-month contract and not significant for the coefficient of expected open interest for the two-month contract. The coefficient of expected open interest is only significant and negative for the lagged 2 days for the three-month contract. The coefficient of expected open interest is significant and negative and increased from lagged 1 to 3 days.

The coefficient of unexpected open interest is significant and negative for lagged 1 , 3 , and 4 days for the spot-month contract and significant and negative for all the lagged days except 2 days in the one-month contract. However, for the two-month contract, only lagged 4 days is significant and positive, and in the three-month contract, lagged 1 and 4 days are significant and negative, and lagged 2 days is significant and positive. The coefficient of unexpected open interest is significant and negative for lagged 1 day for the three-month contract but significant and positive for lagged 2 and 4 days. While the coefficient of unexpected open interest is significant and positive for lagged 2 and 3 days for the three-month contract, it is significant and negative for lagged 5 days.

This finding is consistent with Bessembinder and Seguin (1993). The relationship between unexpected trading volume and the volatility of return for crude palm oil price supports MDH and SIAH. However, for the other components, they do not support MDH or SIAH. This finding is in line with Bessembinder and Seguin (1993), Ragunathan and Peker (1997), Watanabe (2001), and Boonvorachote and Lakmas (2016).

\section{Conclusions}

This paper investigates both contemporaneous and lead-lag relationships between the volatility of return and trading activity on the Malaysian Crude Palm Oil Futures. We partition the trading volume and open interest into expected and unexpected components.

We find a significant contemporaneous negative effect for the one-month contract and a significant contemporaneous positive effect for the nine-month contract between the expected trading volume and the volatility of return. The contemporaneous relationship of the unexpected trading volume is positive and significant to the volatility of return for all contracts except the spot-month contract. On the other hand, the contemporaneous relationship of the expected open interest is negative and significant for the volatility of return for the spot-month contract and nine-month contract. Furthermore, the contemporaneous relationship between the unexpected open interest and the volatility of return is negative and significant for the one-month contract, three-month contract, and nine-month contract.

In general, we also found that there is a lead-lag relationship between the volatility of return, trading volume, and open interest in Malaysian Crude Palm Oil Futures. The unexpected component of trading volume and open interest had a higher impact compared to the expected component of trading volume and open interest on the volatility of return.

The findings of this paper are important to the investors, risk managers, regulators, and policymakers. Investors and risk managers may apply the information of this research to estimate the risk of Malaysian Crude Palm Oil Futures with trading volume and open interest, which will lead to the creation of more reliable hedging strategies for investment purposes. Besides that, regulators and policymakers may use the information in this research to make decisions upon the appropriateness of their policies in the crude palm oil futures market in Malaysia. 
It is undeniable that crude palm oil is one of the major contributors to Malaysia's economy. The finding of this research can be utilized as a reference for designing policy on crude palm oil. Nevertheless, the business sector can utilise the finding of this research to manage their investment in crude palm oil based on the information from the trading volume and open interest of crude palm oil. Moreover, the investors can also use this research as a base for their trading knowledge to increase their short-run return forecasts (Go and Lau 2020b).

Rossi and De Magistris (2013) and Naeem et al. (2020) show that trading volume and volatility of return have an asymmetric behaviour and they are heavy tailed. This is because, when the returns and volumes are high, the tail dependence will be stronger. Therefore, the dependency between the trading activities and volatility of return may vary from the estimation in the normal distribution assumption during extreme condition. Thus, it would be interesting to examine the tail dependency trading activities and the volatility of return in the future.

A possible direction for future research could be the use of the proposed variable of this research to forecast the return and its risk. Because trading volume and open interest significantly affect the volatility or return, it may be applied as the input for machine learning for forecasting. Another suggestion for future research is to investigate the higher order relationship, such as whether skewness and kurtosis are affected by the trading volume and open interest.

Author Contributions: Conceptualization, X.W.Y. and H.H.L.; Data curation, X.W.Y.; Formal analysis, X.W.Y.; Methodology, H.H.L.; Supervision, H.H.L.; Validation, H.H.L.; Writing-original draft, X.W.Y. and H.H.L.; Writing-review \& editing, H.H.L. All authors have read and agreed to the published version of the manuscript.

Funding: Incentive GOT Grant No. 1001/PSOSIAL/822009 by Universiti Sains Malaysia is acknowledged.

Data Availability Statement: Data is available upon request.

Conflicts of Interest: The authors declare no conflict of interest.

\section{References}

Andersen, Torben G., and Tim Bollerslev. 1998. Answering the skeptics: Yes, standard volatility models do provide accurate forecasts. International Economic Review 39: 885-905. [CrossRef]

Balcilar, Mehmet, Elie Bouri, Rangan Gupta, and David Roubaud. 2017. Can volume predict Bitcoin returns and volatility? A quantiles-based approach. Economic Modelling 64: 74-81. [CrossRef]

Bessembinder, Hendrik, and Paul J. Seguin. 1993. Price volatility, trading volume, and market depth: Evidence from futures markets. Journal of Financial and Quantitative Analysis 28: 21-39. [CrossRef]

Biswal, Pratap Chandra, and Anshul Jain. 2019. Should central banks use the currency futures market to manage spot volatility? Evidence from India. Journal of Multinational Financial Management 52: 100596. [CrossRef]

Black, Fischer. 1986. Noise. Journal of Finance 41: 529-43. [CrossRef]

Bollerslev, Tim. 1986. Generalized autoregressive conditional heteroskedasticity. Journal of Econometrics 31: 307-27. [CrossRef]

Boonvorachote, Tanachote, and Kritika Lakmas. 2016. Price volatility, trading volume, and market depth in Asian commodity futures exchanges. Kasetsart Journal of Social Science 37: 53-58. [CrossRef]

Bouri, Elie, Chi Keung Marco Lau, Brian Lucey, and David Roubaud. 2019. Trading volume and the predictability of return and volatility in the cryptocurrency market. Finance Research Letters 29: 340-46. [CrossRef]

Canarella, Giorgio, and Stephen K. Pollard. 2003. The mixture of distribution hypothesis and the Russian stock market. Journal of Business E Economics Research, 1. [CrossRef]

Chan, Kam C., Hung-Gay Fung, and Wai K. Leung. 2004. Daily volatility behavior in Chinese futures markets. International Finance Markets, Institutions, and Money 14: 491-505. [CrossRef]

Chen, Gong-Meng, Michael Firth, and Oliver M. Rui. 2001. The dynamic relation between stock returns, trading volume, and volatility. The Financial Review 38: 153-74. [CrossRef]

Chuang, Wen-I., Hsiang-Hsi Liu, and Rauli Susmel. 2012. The bivariate GARCH approach to investigating the relation between stock returns, trading volume, and return volatility. Global Finance Journal 23: 1-15. [CrossRef]

Clark, Peter K. 1973. A subordinated stochastic process model with finite variance for speculative prices. Econometrica 41: 135-55. [CrossRef] 
Copeland, Thomas E. 1976. A model of asset trading under the assumption of sequential information arrival. Journal of Finance 31: 1149-68. [CrossRef]

Copeland, Thomas E. 1977. A probability model of asset trading. Journal of Financial and Quantitative Analysis 12: 563-98. [CrossRef]

Copeland, Thomas E., and Daniel Friedman. 1987. The effect of sequential information arrival on asset prices: An experimental study. Journal of Finance 42: 763-97. [CrossRef]

Daigler, Robert T., and Marilyn K. Wiley. 1999. The impact of trader type on the futures volatility-volume relation. Journal of Finance 54: 2297-316. [CrossRef]

Darolles, Serge, Gaëlle Le Fol, and Gulten Mero. 2017. Mixture of distribution hypothesis: Analyzing daily liquidity frictions and information flows. Journal of Econometrics 201: 367-83. [CrossRef]

Dompok, B. G. 2011. Deepening Malaysia's palm oil advantage. In Economic Transformation Programme, a Roadmap for Malaysia. Kuala Lumpur: Office of the Prime Minister, chp. 9. pp. 281-314.

Engle, Robert F. 1982. Autoregressive conditional heteroscedasticity with estimates of the variance of United Kingdom inflation. Econometrica 50: 987-1007. [CrossRef]

Engle, Robert. 2001. GARCH 101: The use of ARCH/GARCH models in applied econometrics. Journal of Economic Perspectives 15: 157-68. [CrossRef]

Epps, Thomas W., and Mary Lee Epps. 1976. The stochastic dependence of security price changes and transaction volume: Implications for the mixture-of-distribution hypothesis. Econometrica 44: 305-21. [CrossRef]

Ezzat, Hassan, and Berna Kirkulak-Uludag. 2016. Information arrival and volatility: Evidence from the Saudi stock exchange (Tadawul). Panoeconomicus 64: 45-59. [CrossRef]

Fung, Hung-Gay, and Gary A. Patterson. 1999. The dynamic relationship of volatility, volume and market depth in currency futures markets. Journal of International Financial Markets, Institution and Money 9: 33-59. [CrossRef]

Girma, Paul Berhanu, and Mbodja Mougoué. 2002. An empirical examination of the relation between futures spreads volatility, volume, and open interest. Journal of Futures Markets: Futures, Options, and Other Derivative Products 22: 1083-102. [CrossRef]

Go, You-How, and Wee-Yeap Lau. 2016. Information Arrival between Price Change and Trading Volume in Crude Palm Oil Futures Market: A Non-linear Approach. The Journal of Asian Finance, Economics and Business 3: 79-91. [CrossRef]

Go, You-How, and Wee-Yeap Lau. 2020a. The impact of global financial crisis on informational efficiency: Evidence from price-volume relation in crude palm oil futures market. Journal of Commodity Markets 17: 100081. [CrossRef]

Go, You-How, and Wee-Yeap Lau. 2020b. Does Trading Volume explain the Information Flow of Crude Palm Oil Futures Returns? Review of Finance \& Banking 12: 115-36.

Graczyk, Michelle B., and Silvio M. Duarte Queiros. 2018. Volatility-Trading volume intraday correlation profiles and its nonstationary features. Physica A: Statistical Mechanics and Its Applications 508: 28-34. [CrossRef]

Grammatikos, Theoharry, and Anthony Saunders. 1986. Future price variability: A test of maturity and volume effects. Journal of Business 59: 319-30. [CrossRef]

Hansen, Peter R., and Asger Lunde. 2005. A forecast comparison of volatility models: Does anything beat a GARCH (1,1). Journal of Applied Econometrics 20: 873-89. [CrossRef]

Harris, Lawrence. 1986. Cross-security tests of the mixture of distribution hypothesis. Journal of Financial and Quantitative Analysis 21: 39-46. [CrossRef]

Jarque, Carlos M., and Anil K. Bera. 1987. A test for normality of observations and regression residuals. International Statistical Review/Revue Internationale de Statistique 55: 163-72. [CrossRef]

Jenning, Robert H., Laura T. Starks, and John C. Fellingham. 1981. An equilibrium model of asset trading with sequential information arrival. Journal of Finance 36: 143-61. [CrossRef]

Kao, Yu-Sheng, Hwei-Lin Chuang, and Yu-Cheng Ku. 2019. The empirical linkages among market returns, return volatility, and trading volume: Evidence from the S\&P 500 VIX Futures. North American Journal of Economics and Finance, 100871, in press.

Karpoff, Jonathan M. 1987. The relation between price changes and trading volume: A survey. Journal of Financial and Quantitative Analysis 22: 109-26. [CrossRef]

Kim, Oliver, and Robert E. Verrecchia. 1991. Trading volume and price reactions to public announcements. Journal of Accounting Research 29: 302-21. [CrossRef]

Koubaa, Yosra, and Skander Slim. 2019. The relationship between trading activity and stock market volatility: Does the volume threshold matter? Economic Modelling 82: 168-84. [CrossRef]

Kumar, Satish. 2019. The relationship between trading volume and exchange rate volatility: Linear or nonlinear? International Journal of Managerial Finance 15: 19-38. [CrossRef]

Lamoureux, Christopher G., and William D. Lastrapes. 1990. Heteroskedasticity in stock return data: Volume versus GARCH effects. Journal of Finance 45: 221-29. [CrossRef]

Lee, Bong-Soo, and Oliver M. Rui. 2002. The dynamic relationship between stock returns and trading volume: Domestic and cross-country evidence. Journal of Banking \& Finance 26: 51-78.

Liew, Keng Yap, and Robert Brooks. 1998. Returns and volatility in the Kuala Lumpur crude palm oil futures market. Journal of Futures Markets 18: 985-99. [CrossRef]

Mougoué, Mbodja, and Raj Aggarwal. 2011. Trading volume and exchange rate volatility: Evidence for the sequential arrival of information hypothesis. Journal of Banking E Finance 35: 2690-703. 
Naeem, Muhammad, Elie Bouri, Gideon Boako, and David Roubaud. 2020. Tail dependence in the return-volume of leading cryptocurrencies. Finance Research Letters 36: 101326. [CrossRef]

Pati, Pratap Chandra. 2008. The relationship between price volatility, trading volume and market depth: Evidence from an emerging Indian stock index futures market. South Asian Journal of Management 15: 25-46.

Pyun, Chong Soo, Sa Young Lee, and Kiseok Nam. 2000. Volatility and information flows in emerging equity markets: A case of the Korean stock exchange. International Review of Financial Analysis 9: 405-20. [CrossRef]

Ragunathan, Vanitha, and Albert Peker. 1997. Price variability, trading volume, and market depth: Evidence from the Australian futures market. Applied Financial Economics 7: 447-54. [CrossRef]

Ripple, Ronald D., and Imad A. Moosa. 2009. The effect of maturity, trading volume, and open interest on crude oil futures price range-based volatility. Global Finance Journal 20: 209-19. [CrossRef]

Rogalski, Richard J. 1978. The dependence of prices and volume. The Review of Economics and Statistics 60: 268-74. [CrossRef]

Rossi, Eduardo, and Paolo Santucci De Magistris. 2013. Long memory and tail dependence in trading volume and volatility. Journal of Empirical Finance 22: 94-112. [CrossRef]

Sensoy, Ahmet, and Süleyman Serdengeçti. 2019. Intraday volume-volatility nexus in the FX markets: Evidence from an emerging market. International Review of Financial Analysis 64: 1-12. [CrossRef]

Slim, Skander, and Meriam Dahmene. 2016. Asymmetric information, volatility components and the volume-volatility relationship for the CAC40 stocks. Global Finance Journal 29: 70-84. [CrossRef]

Tauchen, George E., and Mark Pitts. 1983. The price variability-volume relationship on speculative markets. Econometrica 51: 485-505. [CrossRef]

Watanabe, Toshiaki. 2001. Price volatility, trading volume, and market depth: Evidence from the Japanese stock index futures market. Applied Financial Economics 11: 651-58. [CrossRef] 